\title{
Oestrogen and seasonal effects on the production of an oestrus-associated glycoprotein in oviducal fluid of sheep
}

\author{
R. Sutton, C. D. Nancarrow and A. L. C. Wallace \\ CSIRO, Division of Animal Production, P.O. Box 239, Blacktown, New South Wales 2148, Australia
}

\begin{abstract}
Summary. In 14 cyclic ewes, the oestrus-associated glycoprotein in the oviducal fluid was never detected between Days 7 and -2 of the oestrous cycle and it was present in $5 \%$ of fluid samples collected on Day $-1,59 \%$ on Day $0,96 \%$ on Day $1,100 \%$ on Day $2,79 \%$ on Day $3,31 \%$ on Day $4,16 \%$ on Day 5 , and $4 \%$ on Day 6 . Its presence generally coincided with the period of high flow rate of oviducal fluid which occurs around oestrus. The duration of detectable levels of the oestrus-associated glycoprotein did not vary significantly during the breeding season from a mean $( \pm$ s.d.) of $3.9 \pm 1.0$ days. However, the peak flow rate of oviducal fluid dropped from $1.63 \pm 0.50$ (early) to $1.38 \pm 0.40$ (mid-) and to $0.85 \pm 0.21 \mathrm{ml} /$ day late in the season. Anoestrous ewes (3) induced to ovulate by treatment with progesterone implants and gonadotrophin showed low peak fluid flow rates $(0.92 \pm 0.30 \mathrm{ml} /$ day $)$ and the presence of the oestrusassociated glycoprotein for a shorter period $(2 \cdot 7 \pm 0 \cdot 7$ days). Pregnancy $(\mathrm{N}=3)$ did not appear to prolong the production of the protein. The injection of $25 \mu \mathrm{g}$ oestradiol benzoate into 3 anoestrous, 2 mid-cycle and 9 ovariectomized ewes caused an increase in fluid flow rate and appearance of the glycoprotein 1-2 days later. The glycoprotein was present for a longer period in response to the exogenous oestrogen $-6.8 \pm 1.6$ days in the ovariectomized ewes, $7.9 \pm 1.3$ days in anoestrous ewes, and $8.4 \pm 0.8$ days in the dioestrous ewes. In the ovariectomized ewes a seasonal effect was observed on fluid flow rates with lower peak values in response to oestrogen injection occurring later in the breeding season. The manipulation of progesterone alone did not cause production of the oestrus-associated glycoprotein.
\end{abstract}

\section{Introduction}

Oviducal fluid contains most if not all of the proteins found in plasma, but at a much lower concentration. In addition, a number of proteins specific to oviducal fluid have been described in a variety of species and several of these proteins are produced only at particular stages of the oestrous cycle (Mastroianni \& Go, 1979; Edwards, 1980). In the sheep, there is an oestrus-associated glycoprotein in oviducal fluid which is present for 3-6 days of the oestrous cycle appearing on Day 0 , the day of oestrus, or Day 1 when ovulation and fertilization occur, and usually persisting at least until the beginning of Day 4 when the embryo passes into the uterus (Sutton, Nancarrow, Wallace \& Rigby, 1984a).

This glycoprotein has a native molecular weight $\left(M_{\mathrm{r}}\right)$ of several million, a subunit $M_{\mathrm{r}}$ of $70-90000$, an isoelectric point of $4 \cdot 7$ and galactose, $N$-acetylgalactosamine and fucose residues accessible to lectin binding (Sutton et al., 1984a; Sutton, Wallace \& Nancarrow, 1985). Since this protein also appears to bind to spermatozoa (Sutton, Wallace, Engel \& Nancarrow, 1984b), it may play a role in fertilization, or in protecting spermatozoa from the maternal immune system.

In avian and mammalian species, specific oviducal proteins have been described which appear around the time of ovulation or after oestrogen administration (Mastroianni \& Go, 1979; Edwards, 1980). The timing of the appearance of the oestrus-associated glycoprotein led to the hypothesis 
that it is induced by the marked preovulatory increase of oestradiol-17 $\beta$ concentrations measured in plasma from the uterotubal vein by Cox, Mattner \& Thorburn (1971). Furthermore, oestradiol benzoate is known to increase the flow rate of oviducal fluid in ovariectomized ewes (Restall, 1966; McDonald \& Bellve, 1969) and in cyclic ewes the presence of the oestrus-associated glycoprotein coincided with the elevated fluid flow rate during oestrus and metoestrus (Sutton et al., 1984a). Since the peak oviducal fluid flow rates are lower late in the breeding season than in mid- (Sutton et al., 1984a) or early season cycles (Murray, Goode \& Linnerud, 1969), experiments were carried out at different times of the year. Their aim was to establish whether the production of the oestrusassociated glycoprotein also responded to seasonal changes and the injection of oestradiol benzoate. Preliminary data on the effects of oestradiol benzoate in ovariectomized ewes have been published elsewhere (Nancarrow, Sutton \& Wallace, 1983).

\section{Materials and Methods}

\section{Oviducal fluid collection}

Both oviducts of 32 adult Merino ewes were catheterized as described by Sutton et al. (1984a). Since some catheters were maintained for a long time (up to 96 days; mean 36 days), data were often collected for several cycles or treatments for one ewe. Fluid samples were collected daily at 08:30 h except at weekends when 48 - or $72-\mathrm{h}$ collection periods were sometimes used. On these occasions it was assumed that an equal proportion of the volume resulted from each day. The weekend sampling sometimes prevented assessment of the duration of detectable levels of the oestrus-associated glycoprotein. Fluid volumes were estimated by weight and samples were stored at $-20^{\circ} \mathrm{C}$ after centrifugation to remove cellular debris.

\section{Treatment groups}

Cyclic ewes. Subcutaneous progesterone implants $(375 \mathrm{mg}$, Sil Estrus, Ceva Chemicals, Australia) were used in most ewes to synchronize the first oestrus after catheterization. The days of the cycle were assigned by defining the day of the highest flow rate as Day 1, as previously found by Perkins, Goode, Wilder \& Henson (1965) and Bellve \& McDonald (1968), and substantiated by measurement of plasma LH concentrations (Sutton et al., 1984a). Using this method the 18 completed oestrous cycles were $17.4 \pm 1 \cdot 1$ days long (mean \pm s.d.). In the 12 ewes (with 18 catheters) in which the first oestrus was synchronized using progesterone implants, Day 1 by this definition occurred $3.17 \pm 0.70$ days (mean \pm s.d.) after removal of the implants. Two cyclic ewes were given intramuscular injections of $25 \mu \mathrm{g}$ oestradiol benzoate (Steraloids, Inc., Pawlings, New York, U.S.A.) in $0.5 \mathrm{ml}$ safflower oil.

Pregnant ewes. Four ewes were catheterized in April, 3 days (2) or 4 days (2) after mating with entire rams. Oviducal fluid was collected for 7 days after which the ewes were killed and the uteri flushed with saline. Pregnancy was confirmed by the collection of an embryo from 3 of the ewes.

Anoestrous ewes. Two groups of 3 ewes were catheterized in the non-breeding season and none of the ovaries had corpora lutea or large follicles at the time of surgery. In the first group artificial oestrous cycles (13-14 days) were induced by treatment with a progesterone implant for 5-7 days and injection of 200 i.u. PMSG (Folligon: Intervet Australia Pty. Ltd, Lane Cove, New South Wales, Australia) at the time of implant removal. For the second and third cycles, $100 \mu \mathrm{g}$ cloprostenol (Estrumate, ICI, Australia Pty. Ltd, Melbourne, Victoria, Australia) were also given at the time of implant insertion. The days of the cycle were assigned in the same way as in the cyclic ewes. Plasma samples obtained from jugular blood of these ewes were assayed for progesterone (data not shown) and luteinizing hormone (LH) (Radford, Nancarrow \& Findlay, 1978). The LH assay had a sensitivity of $0.25 \mathrm{ng}$, an intra-assay CV of $9 \%$ and used NIH-LH-S15 as the standard. 
The anoestrous ewes in the second group were given 3 or 4 single injections of oestradiol benzoate at 5-10-day intervals. At the end of the experiment in late December, 1 ewe was still anoestrous, but both of the other 2 had a mid-cycle corpus luteum. (This was probably due to the onset of the breeding season rather than the result of treatment, since some untreated ewes in the same flock also showed ovarian activity.)

Ovariectomized ewes. Bilateral ovariectomy was carried out at the same time as oviducal cannulation and ewes were left for at least 4 days before any treatment was given. In the first experiment after a 12-day period without treatment, 2 ewes were each given $25 \mu \mathrm{g}$ oestradiol benzoate 3 times at 7-day intervals, 2 others were given progesterone implants for 7 days followed by 7 days without, and the remaining 2 were left as controls. After these initial treatments, 3 of the ewes were given oestradiol benzoate at 14-day intervals and one of the previous controls was treated with both progesterone and oestradiol benzoate; the oestradiol benzoate was given 1 day after implant removal, and 2 days before the next implant. In later experiments 3 ewes were injected with $25 \mu \mathrm{g}$ oestradiol benzoate at 14-day intervals.

\section{Assessment of the presence of the oestrus-associated glycoprotein in oviducal fluid}

The protein concentration of oviducal fluid was determined by absorbance (Whitaker \& Granum, 1980) and sequential fluid samples from each oviduct were compared by loading volumes equivalent to $60 \mu \mathrm{g}$ protein, diluted in Laemmli extracting solution, onto SDS slab gels (Laemmli, 1970; Sutton et al., 1984a). For some samples from late season cyclic ewes and induced cycles in anoestrous ewes, up to $80 \mu \mathrm{g}$ protein were loaded, but this appeared not to alter the assessment. All gels included molecular weight standards and were stained with Coomassie blue and later silverstained. The oestrus-associated glycoprotein was usually easily visible after Coomassie blue staining, but the detection of low levels of the glycoprotein was aided by silver staining because it stained orange compared with the brown of other proteins. Samples were scored by two independent observers as positive (1) or not detectable (0) for the glycoprotein. The sensitivity of this assay is less than $100 \mathrm{ng}$, estimated on the staining of bovine serum albumin and allowing for the diffuseness of the glycoprotein band. A score of 0.5 was given to fainter than normal bands which were observed in some sequences on the first or last day that the glycoprotein was present in fluid, and which were interpreted as indicating that the glycoprotein had been produced for less than half the 24-h period. The incidence of the glycoprotein was then calculated as a percentage of the total of the scores divided by the number of scores. Since it could be argued that using this method (in which a constant amount of protein was loaded for each sample) an increase in another protein could reduce the apparent but not actual amount of glycoprotein, samples from 4 cycles and 2 oestradiol benzoate treatments were reanalysed by loading a constant amount $(6 \mu \mathrm{l})$ of oviducal fluid. This had no effect on the score.

\section{Results}

The changes in oviducal fluid flow rates and the presence of the oestrus-associated glycoprotein during the oestrous cycle at different stages of the breeding season are shown in Fig. 1. These results show that the peak flow rate of oviducal fluid declined during the breeding season and that the presence of the oestrus-associated glycoprotein coincided with the elevated fluid flow rate between Days 0 and 3. The protein was never detected between Day 7 and Day -2 of the cycle. The duration of detectable levels of the oestrus-associated glycoprotein did not vary significantly during the breeding season (Table 1).

Anoestrous ewes that were induced to cycle responded with a low peak flow rate and a short duration of detectable levels of the oestrus-associated glycoprotein (Fig. 2; Table 1). LH was 

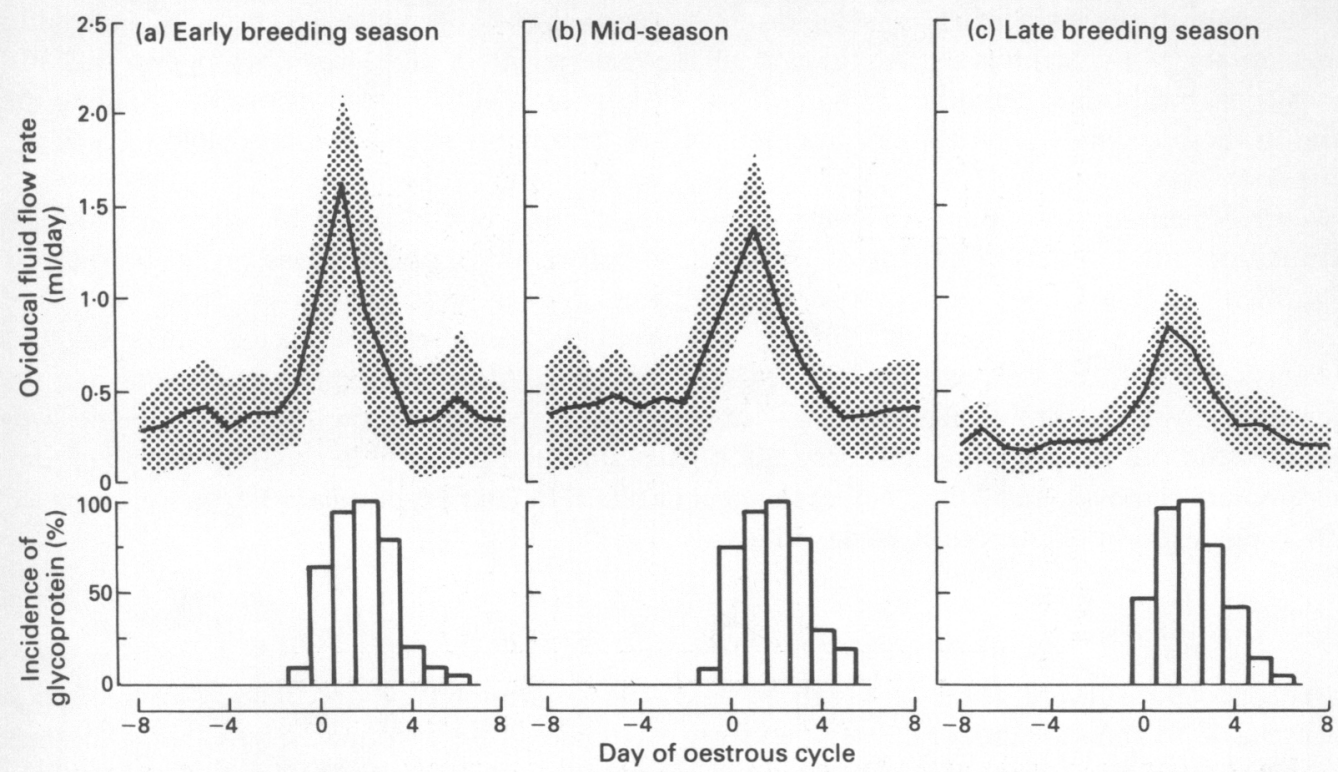

Fig. 1. Changes in oviducal fluid of intact cyclic ewes at different times of the year. Data are given for daily fluid samples from (a) 12 oestrous cycles from 8 ewes collected between late January and March; (b) 12 cycles from 3 ewes in April and May; (c) 20 cycles from 6 ewes in June and July. The fluid flow rate means \pm s.d. are shown by the line and stippled area. The incidence of glycoprotein is the percentage of samples which contained the oestrus-associated glycoprotein (see 'Materials and Methods').

Table 1. Peak flow rates and duration of the oestrus-associated glycoprotein (EGP) in oviducal fluid from ewes in different treatment groups

\begin{tabular}{|c|c|c|c|c|c|}
\hline \multirow{2}{*}{ Cyclic ewes } & \multirow[b]{3}{*}{ Jan.-March } & \multicolumn{2}{|c|}{$\begin{array}{l}\text { Peak fluid flow } \\
\text { rate (ml/day) }\end{array}$} & \multicolumn{2}{|c|}{$\begin{array}{l}\text { Duration of EGP } \\
\text { presence (days) }\end{array}$} \\
\hline & & & & & \\
\hline Early breeding season & & $1 \cdot 63 \pm 0.50^{\mathrm{bc}}$ & (12) & $3 \cdot 9 \pm 1 \cdot 0^{\mathrm{c}}$ & $(10)$ \\
\hline Mid-breeding season & April-May & $1 \cdot 38 \pm 0 \cdot 40^{c}$ & (12) & $4 \cdot 1 \pm 0 \cdot 8^{c}$ & (10) \\
\hline Late breeding season & June-July & $0.85 \pm 0.21^{\mathrm{c}}$ & (20) & $3 \cdot 6 \pm 1 \cdot 1^{c}$ & (15) \\
\hline $\begin{array}{l}\text { Mid-cycle + oestradiol } \\
\text { benzoate }\end{array}$ & May-July & $1 \cdot 70 \pm 0 \cdot 31^{\mathrm{bc}}$ & (5) & $8 \cdot 4 \pm 0 \cdot 8^{a}$ & (4) \\
\hline $\begin{array}{l}\text { Anoestrous ewes } \\
\text { Induced cycles } \\
\quad+\text { oestradiol benzoate }\end{array}$ & $\begin{array}{l}\text { Oct.-Nov. } \\
\text { Nov.-Dec. }\end{array}$ & $\begin{array}{l}0.92 \pm 0.30^{\mathrm{e}} \\
1.24 \pm 0.31^{\text {cd }}\end{array}$ & $\begin{array}{l}(9) \\
(9)\end{array}$ & $\begin{array}{l}2 \cdot 7 \pm 0.7^{\mathrm{d}} \\
7 \cdot 9 \pm 1 \cdot 3^{\mathrm{ab}}\end{array}$ & $\begin{array}{l}(5) \\
(5)\end{array}$ \\
\hline \multicolumn{6}{|c|}{ Ovariectomized ewes + oestradiol benzoate } \\
\hline Early breeding season & Feb.-March & $2 \cdot 13 \pm 0 \cdot 28^{\mathrm{a}}$ & (8) & $7 \cdot 5 \quad a b$ & (2) \\
\hline Mid-breeding season & April-May & $1.96 \pm 0.24^{\mathrm{ab}}$ & (5) & $7.7 \pm 1.4^{\mathrm{ab}}$ & (13) \\
\hline Late breeding season & June-July & $0.98 \pm 0.42^{\mathrm{de}}$ & (8) & $6 \cdot 1 \pm 1 \cdot 7^{b}$ & (4) \\
\hline
\end{tabular}

Values are mean \pm s.d. for the number of cycles given in parentheses.

Values given different superscript letters are significantly different from others in the same column $(P<0.05$, Student's $($ test).

measured in the plasma of these ewes and the results indicate that elevated values occurred at the last bleed $(10 \mathrm{~h})$ on Day 0 or at $0 \mathrm{~h}$ on Day 1, with the oestrus-associated glycoprotein appearing on either of these 2 days (Table 2). 

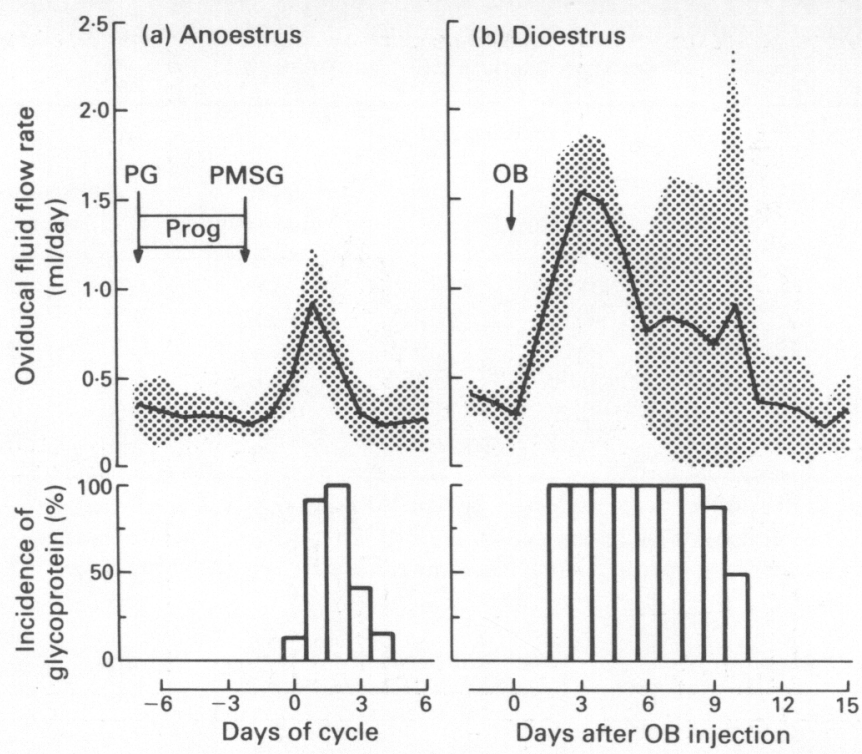

Fig. 2. Changes in oviducal fluid from intact ewes subjected to hormonal manipulation. Results were from (a) 9 oestrous cycles induced by treatment with prostaglandin (PG), progesterone implants (Prog) and PMSG in 3 anoestrous ewes in October and November. The timing of treatment is as indicated, or in 2 cycles 1 day earlier; (b) 5 responses to a single injection of $25 \mu \mathrm{g}$ oestradiol benzoate $(\mathrm{OB})$ in 2 ewes in May and July given between Day 7 and 9 of the oestrous cycle. Results are represented as in Fig. 1.

Table 2. Similar timing of the appearance of the oestrus-associated glycoprotein (EGP) and high LH concentrations $(\mathrm{ng} / \mathrm{ml})$ in plasma during artificially induced cycles in anoestrous ewes

\begin{tabular}{|c|c|c|c|c|c|c|c|c|c|c|c|}
\hline \multirow{3}{*}{$\begin{array}{l}\text { Day of } \\
\text { cycle* }\end{array}$} & \multirow{3}{*}{$\begin{array}{l}\text { Time } \\
\text { (h) } \dagger\end{array}$} & \multicolumn{4}{|c|}{ Ewe 1} & \multicolumn{4}{|c|}{ Ewe 2} & \multirow{2}{*}{\multicolumn{2}{|c|}{$\begin{array}{c}\text { Ewe } 3 \\
\text { 1st cycle }\end{array}$}} \\
\hline & & \multicolumn{2}{|c|}{ 1st cycle } & \multicolumn{2}{|c|}{ 2nd cycle } & \multicolumn{2}{|c|}{ 2nd cycle } & \multicolumn{2}{|c|}{ 3rd cycle } & & \\
\hline & & LH & EGP & LH & EGP & LH & EGP & LH & EGP & LH & EGP \\
\hline Day -2 & 0 & & - & & - & $\mathrm{P} \downarrow$ & - & & - & $\mathbf{P} \downarrow$ & - \\
\hline Day -1 & 0 & $P \downarrow$ & - & $\mathbf{P} \downarrow$ & - & 4 & - & $P \downarrow$ & - & 4 & - \\
\hline Day 0 & $\begin{array}{r}0 \\
5 \\
10\end{array}$ & 3 & - & $\begin{array}{r}8 \\
\leq 128 \\
\end{array}$ & - & $\begin{array}{r}4 \\
3 \\
23 \\
\end{array}$ & - & $\begin{array}{l}10 \\
35 \\
\end{array}$ & + & $\begin{array}{l}3 \\
3 \\
3\end{array}$ & - \\
\hline Day 1 & $\begin{array}{r}0 \\
5 \\
10\end{array}$ & $\begin{array}{l}\frac{64}{24} \\
11\end{array}$ & + & $\begin{array}{l}6 \\
6 \\
6\end{array}$ & + & $\begin{array}{l}3 \\
3 \\
2\end{array}$ & + & $\begin{array}{r}12 \\
9 \\
9\end{array}$ & + & $\begin{array}{r}\frac{47}{4} \\
1\end{array}$ & + \\
\hline Day 2 & 0 & 2 & + & 7 & + & 2 & + & 9 & + & 1 & + \\
\hline
\end{tabular}

* The day with the highest flow of oviducal fluid was arbitrarily defined as Day 1 of the cycle.

† The time of blood sampling is expressed as the number of hours since the beginning of fluid collection at $08: 30 \mathrm{~h}$ on that day.

$P \downarrow$ Indicates the time of removal of progesterone implants and injection of gonadotrophin. High LH values are underlined. Daily fluid samples were scored for the presence $(+)$ or absence $(-)$ of the oestrus-associated glycoprotein.

Anoestrous ewes were also induced to produce the oestrus-associated glycoprotein by the injection of $25 \mu \mathrm{g}$ oestradiol benzoate. This treatment caused a greater increase in oviducal fluid flow rate and prolonged production of the oestrus-associated glycoprotein compared with the induced cycles (Table 1). 
Table 3. Effect of pregnancy on the production of oviducal fluid ( $\mathrm{ml} /$ day) and the oestrus-associated glycoprotein

\begin{tabular}{|c|c|c|c|c|c|c|}
\hline \multirow{3}{*}{$\begin{array}{l}\text { Day of cycle } \\
\text { or pregnancy }\end{array}$} & \multicolumn{4}{|c|}{ Ewes mated } & \multirow{2}{*}{\multicolumn{2}{|c|}{$\begin{array}{l}\text { Cyclic ewes } \\
\text { (unmated) }\end{array}$}} \\
\hline & \multicolumn{3}{|c|}{ Pregnant } & \multirow{2}{*}{$\begin{array}{c}\begin{array}{c}\text { Not } \\
\text { pregnant }\end{array} \\
0.25^{+}\end{array}$} & & \\
\hline & & $0.70^{+}$ & & & $1.00^{+}$ & $0.75^{+}$ \\
\hline 4 & $0.60^{-}$ & $0 \cdot 10^{-}$ & $1.20^{-}$ & $0.50^{-}$ & $0.75^{+} /^{-}$ & $0.45^{-}$ \\
\hline 5 & $0.60^{-}$ & $0 \cdot 10^{-}$ & $1.00^{-}$ & $0.05^{-}$ & $0.40^{-}$ & $0.50^{-}$ \\
\hline 6,7 & $0 \cdot 30^{-}$ & 0.00 & $0.75^{-}$ & $0.05^{-}$ & $0.08^{-}$ & $0.45^{-}$ \\
\hline 8 & $0.35^{-}$ & $0 \cdot 20^{-}$ & $0.70^{-}$ & $0.05^{-}$ & $0.50^{-}$ & $0.40^{-}$ \\
\hline 9 & $0.40^{-}$ & $0.25^{-}$ & $0.60^{-}$ & $0.05^{-}$ & $0.60^{-}$ & $0.55^{-}$ \\
\hline
\end{tabular}

All oviducal fluid samples were collected in April. Pregnancy was confirmed in 3 of the 4 mated ewes by collection of an embryo on Day 10 . The presence $(+)$ or absence $(-)$ of the oestrus-associated glycoprotein in each sample is indicated by the superscript.
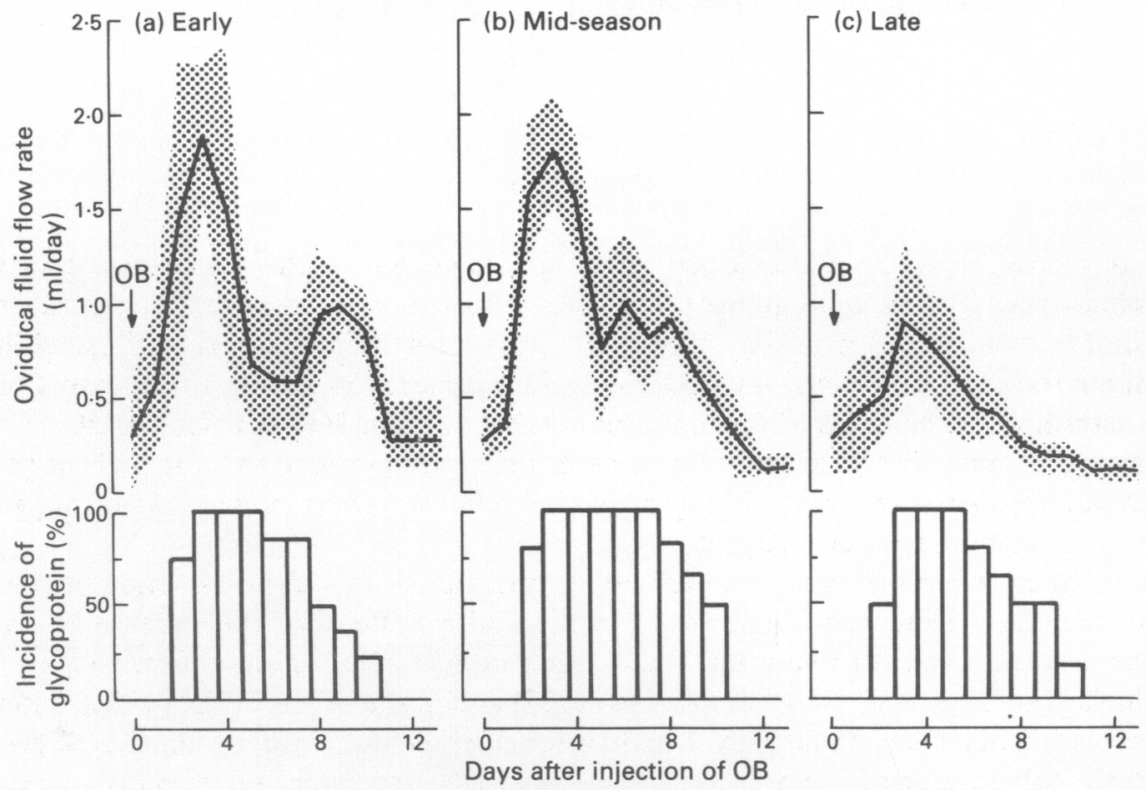

Fig. 3. Changes in oviducal fluid of ovariectomized ewes after the single injection of $25 \mu \mathrm{g}$ oestradiol benzoate $(\mathrm{OB})$ at different times of the year. Results were from (a) 8 injection responses in 3 ewes studied in February and March; (b) 5 injection responses in 1 ewe in April and May; (c) 8 injection responses in 2 ewes in June and July. Results are represented as in Fig. 1.

Cyclic ewes that were given oestradiol benzoate during dioestrus also responded with the appearance of the oestrus-associated glycoprotein and a higher oviducal flow rate (Fig. 2). The durations of production of detectable levels of the glycoprotein and the increased oviducal fluid were longer than in normal cycles (Figs 1 \& 2; Table 1).

Oviducal fluid was collected from 3 pregnant ewes after catheterization 3 or 4 days after fertile mating. These samples were compared with those of a ewe treated similarly but which was not pregnant and 2 cyclic ewes (Table 3). Pregnancy did not markedly alter the fluid flow rates for this period, nor did it prolong the production of the oestrus-associated glycoprotein. 
After ovariectomy, ewes produced only a small quantity of oviducal fluid each day with no detectable oestrus-associated glycoprotein, and treatment with progesterone implants alone had no effect. However, on all occasions, the ewes injected with oestradiol benzoate showed both an increase in oviducal fluid production and the appearance of the glycoprotein. In the first experiment the injections were at 7-day intervals which resulted in continuous production of the glycoprotein on 2 out of 4 occasions, and so 14-day intervals were used in later work. Figure 3 illustrates that the oviducal fluid flow rate increased in the $24-48$-h period after injection of oestradiol benzoate (Day 2), with a further increase on Day 3, and that the oestrus-associated glycoprotein was present in over half the Day 2 samples and all samples for Days 3-5. When seasonal effects were analysed, the flow rate response to oestrogen was greater in the ovariectomized ewes in experiments performed early and in the middle of the breeding season compared with the late season (Table 1; Fig. 3). The ovariectomized ewes injected with oestradiol benzoate showed significantly longer production of the oestrus-associated glycoprotein and a higher peak flow rate than did the corresponding cyclic ewes. A single ewe treated 3 times with both oestradiol benzoate and a progesterone implant given 2 days later maintained a high flow rate and glycoprotein secretion for at least 6 days on each occasion (data not shown).

\section{Discussion}

These results provide substantial evidence that the production of the oestrus-associated glycoprotein is influenced by oestrogen. In ovariectomized, anoestrous and dioestrous ewes, the injection of oestradiol benzoate resulted in the appearance of this protein in oviducal fluid. In addition, its appearance in the fluid of ewes on Day 0 or Day 1 of the cycle is consistent with its induction by the peak of oestradiol-17 $\beta$ concentrations in the uterotubal vein on Day -1 (Cox et al., 1971). The similar timing of appearance of the oestrus-associated glycoprotein and the LH surge during induced cycles in anoestrous ewes (this paper) and in cyclic ewes (Sutton et al., 1984a) suggests that oestradiol is the common causative agent.

However, these experiments do not exclude the possibilities that the production of the protein and the concomitant increase in fluid flow rate are indirect effects of the increase in oestrogen. During the oestrous cycle, there are marked changes in both relative blood flow to the oviducts, which is highest on Day - 1 (Brown \& Mattner, 1977) and in the height of the oviducal epithelium which increases from Day -1 to Day 2 and then decreases to a baseline on Day 7 (Willemse, 1975a). Both of these effects have been ascribed to oestrogen and can be induced in ovariectomized ewes by oestrogen (Restall, 1966; Willemse, 1975b; Brown \& Mattner, 1977). It is therefore possible that the increase in fluid flow rate in particular is a secondary effect mediated by the vascular and epithelial changes.

The timing of events in the ovariectomized ewes injected with oestradiol benzoate is similar to that observed in intact cyclic ewes. Oestrus occurred $2(84 \%)$ or $3(16 \%)$ days after injection of $25 \mu \mathrm{g}$ oestradiol benzoate in ovariectomized ewes (Robinson \& Moore, 1956), and so Day 2 in these ewes is equivalent to Day 0 of the cycle. It is on this day that, as for the cyclic ewes, the oestrusassociated glycoprotein appeared in about half the ewes and oviducal fluid flow rates increased substantially with a further small increase on the following day.

However, the oestrus-associated glycoprotein was present for a longer period in each group of ewes injected with oestradiol benzoate than in cyclic ewes. The $25 \mu \mathrm{g}$ dose of oestradiol benzoate has been routinely used in this laboratory to elicit an LH response in ovariectomized ewes (Radford, Wheatley \& Wallace, 1969). This dose also appeared to be within the physiological range from the work of Robinson (1955), which showed that the median effective dose for ovariectomized Suffolk ewes was $64 \mu \mathrm{g}$ to elicit oestrous behaviour and $24 \mu \mathrm{g}$ for characteristic vaginal changes. 
Restall (1966), McDonald \& Bellve (1969) and Willemse (1975b) all used $30 \mu \mathrm{g}$ oestradiol benzoate in ovariectomized ewes to mimic cyclic changes in the oviducal epithelium or fluid flow rates. However, our data and those of Restall (1966) suggest that oestradiol benzoate injected in oil is released over a longer period than the endogenous peak of oestradiol-17 $\beta$ which occurs at pro-oestrus in cyclic ewes. This hypothesis should be tested, since it has implications for many reproductive studies.

The decline in peak flow rates of oviducal fluid as the breeding season progressed confirmed the findings of Restall (1966), Murray et al. (1969) and Sutton et al. (1984a). Restall (1966) suggested that this effect may be due to a seasonal decline in oestrogen concentrations. However, since this seasonal change was also observed in this study in ovariectomized ewes injected with oestradiol benzoate, it appears that the oviducts actually become less responsive to oestrogen late in the breeding season, although the mechanism for this is not clear. There was no significant seasonal effect on the duration of detectable levels of the oestrus-associated glycoprotein in cyclic ewes although it was present for a shorter time in cycles induced in anoestrous ewes. However, the overall production of the glycoprotein would probably be higher early in the season because of the greater volumes of fluid produced, but a quantitative assay for the protein would be needed to establish this fact.

Similar cyclic changes in the oviducal epithelium and in fluid production have been observed for several other mammals including cattle, pigs, rabbits, rats, monkeys and women, so they probably play an important role in reproduction (Perkins, 1974; Stone \& Hamner, 1975; Edwards, 1980). A high flow rate may be needed to ensure an adequate supply of oxygen and nutrients, the removal of waste products, or the distribution of any embryo products involved in the maternal recognition of pregnancy.

The site of synthesis of the oestrus-associated glycoprotein has not been conclusively established. It may be synthesized in oviducal secretory cells and discharged in the granules described by Rüsse \& Liebich (1979) or, as Hollis, Frith, Vaughan, Chapman \& Nancarrow (1984) have suggested, it may be produced by the ciliated cells in the isthmus, where the apocrine secretion of vesicles occurs around the time of oestrus.

Two possible roles for the oestrus-associated glycoprotein are being considered. Firstly, it may be important for fertilization since this protein binds to spermatozoa (Sutton et al., 1984b) and in-vitro fertilization rates for ruminant eggs are enhanced by incubation of oocytes or spermatozoa in the oviduct (Wright \& Bondioli, 1981). Proteoglycans from bovine follicular fluid and their chondroitin sulphate side chains have been shown to enhance the acrosome reaction and fertilization in vitro (Lenz, Ax, Grimek \& First, 1982; Lenz, Ball, Lohse, First \& Ax, 1983) and so the oviducal glycoprotein should also be purified and tested.

Secondly, the oestrus-associated glycoprotein may protect spermatozoa and embryos from the maternal humoral immune system. Oliphant, Cabot, Ross \& Marta (1984) have proposed this role for a family of 3 sulphated glycoproteins from rabbit oviducal fluid, which inhibit complement activity. There are several similarities between the sheep and rabbit glycoproteins. Both can be induced by oestrogen and stain with periodic acid-Schiff reagent and Alcian blue. The 3 rabbit glycoproteins are the major components of the void volume fraction when oviducal fluid is fractionated on a Sephadex G200 column $\left(M_{\mathrm{r}}>500000\right)$ and all appear as a broad band (mean $M_{\mathrm{r}}$ 72000 ) on SDS gels (Oliphant et al., 1984). The oestrus-associated glycoprotein is the major component of the sheep oviducal fluid void volume fraction on Sephacryl 300 columns $\left(M_{\mathrm{r}}\right.$ $>1000000)$ and appears as a broad band $\left(M_{\mathrm{r}} 70-90000\right)$ on SDS gels (Sutton et al., 1984a, b). It is proposed that these glycoproteins bind to spermatozoa and embryos and thus in some way block one of the complement reactions which recognize any maternal antibodies and cause cell lysis.

We thank R. Newman and H. Engel for expert technical assistance and J. Avenell and M. Radford for performing the LH assays. 


\section{References}

Bellve, A.R. \& McDonald, M.F. (1968) Directional flow of Fallopian tube secretion in the Romney ewe. $J$. Reprod. Fert. 15, 357-364.

Brown, B.W. \& Mattner, P.E. (1977) Capillary blood flow in the genital tracts of conscious ewes: cyclic changes and the effect of ovarian hormones. $J$. Endocr. 74, 185-191.

Cox, R.I., Mattner, P.E. \& Thorburn, G.D. (1971) Changes in ovarian secretion of oestradiol-17 $\beta$ around oestrus in the sheep. J. Endocr. 49, 345-346.

Edwards, R.G. (1980) The female reproductive tract. In Conception in the Human Female, pp. 416-524. Academic Press, London.

Hollis, D.E., Frith, P.A., Vaughan, J.D., Chapman, R.E. \& Nancarrow, C.D. (1984) Ultrastructural changes in the oviductal epithelium of Merino ewes during the estrous cycle. Am. J. Anat. 171, 441-456.

Laemmli, U.K. (1970) Cleavage of structural proteins during the assembly of the head of bacteriophage T4. Nature, Lond. 227, 680-685.

Lenz, R.W., Ax, R.L., Grimek, H.J. \& First, N.J. (1982) Protéoglycan from bovine follicular fluid enhances an acrosome reaction in bovine spermatozoa. Biochem. Biophys. Res. Commun. 106, 1092-1098.

Lenz, R.W., Ball, G.D., Lohse, J.K., First, N.L. \& Ax, R.L. (1983) Chondroitin sulfate facilitates an acrosome reaction in bovine spermatozoa as evidenced by light microscopy, electron microscopy and in vitro fertilization. Biol. Reprod. 28, 683-690.

Mastroianni, L., Jr \& Go, K.J. (1979) Tubal secretions. In The Biology of the Fluids of the Female Genital Tract, pp. 335-344. Eds F. K. Beller \& G. F. B. Schumacher. Elsevier/North Holland, Amsterdam.

MeDonald, M.F. \& Bellve, A.R. (1969) Influence of oestrogen and progesterone on flow of fluid from the Fallopian tube in the ovariectomized ewe. J. Reprod. Fert. 20, 51-61.

Murray, F.A., Goode, L. \& Linnerud, A.C. (1969) Effects of season, mating and pregnancy on the volume and protein content of ewe oviduct fluid. J. Anim. Sci. 29, $727-733$.

Nancarrow, C.D., Sutton, R. \& Wallace, A.L. (1983) Oestrogen induction of an oestrus-associated glycoprotein by the sheep oviduct. Proc. Aust. Soc. Reprod. Biol. 15, 103, Abstr.

Oliphant, G., Cabot, C., Ross, P. \& Marta, J. (1984) Control of the humoral immune system within the rabbit oviduct. Biol. Reprod. 31, 205-212.

Perkins, J.L. (1974) Fluid flow of the oviduct. In The Oviduct and its Functions, pp. 119-132. Eds A. D. Johnson \& C. W. Foley. Academic Press, New York.

Perkins, J.L., Goode, L., Wilder, W.A., Jr \& Henson, D.B. (1965) Collection of secretions from the oviduct and uterus of the ewe. J. Anim. Sci. 24, 383-387.

Radford, H.M., Wheatley, I.S. \& Wallace, A.L.C. (1969) The effects of oestradiol benzoate and progesterone on the secretion of luteinizing hormone in the ovariectomized ewe. J. Endocr. 44, 135-136.
Radford, H.M., Nancarrow, C.D. \& Findlay, J.K. (1978) Effect of anaesthesia on ovarian follicular development and ovulation in the sheep subsequent to prostaglandin-induced luteolysis. J. Endocr. 78, 321-327.

Restall, B.J. (1966) The fallopian tube of the sheep II. The influence of progesterone and oestrogen on the secretory activities of the fallopian tube. Aust. J. biol. Sci. 19, 187-197.

Robinson, T.J. (1955) Quantitative studies on the hormonal induction of oestrus in spayed ewes. $J$. Endocr. 12, 163-173.

Robinson, T.J. \& Moore, N.W. (1956) The interaction of oestrogen and progesterone on the vaginal cycle of the ewe. J. Endocr. 14, 97-109.

Rüsse, I. \& Liebich, H.G. (1979) Maturation of secretory granules in the endosalpinx one to four days post coitum in sheep. Cell Tissue Res. 201, 145-158.

Stone, S.L. \& Hamner, C.E. (1975) Biochemistry and physiology of oviductal secretions. Gynecol. Invest. 6 , $234-252$.

Sutton, R., Nancarrow, C.D., Wallace, A.L.C. \& Rigby, N.W. (1984a) Identification of an oestrus-associated glycoprotein in oviducal fluid of the sheep. J. Reprod. Fert. 72, 415-422.

Sutton, R., Wallace, A.L.C., Engel, H. \& Nancarrow, C.D. (1984b) Binding of sheep oviducal fluid proteins to spermatozoa. In Reproduction in Sheep, pp. 140-143. Eds D. R. Lindsay \& D. T. Pearce. Australian Academy of Science, Canberra.

Sutton, R., Wallace, A.L.C. \& Nancarrow, C.D. (1985) Characterisation of a glycoprotein in oviductal fluid by two-dimensional electrophoresis and lectin binding to protein gel blots. Electrophoresis 6, 516-520.

Whitaker, J.R. \& Granum, P.E. (1980) An absolute method for protein determination based on difference in absorbance at 235 and $280 \mathrm{~nm}$. Analyt. Biochem. $109,156-159$.

Willemse, A.H. (1975a) The secretory activity of the epithelium of the ampulla tubae in cyclic ewes: a light microscopical study. Tijdschr. Diergeneesk. 100, 84.94.

Willemse, A.H. (1975b) The influence of oestradiol benzoate and progesterone on the secretory activity of the epithelium of the ampulla tubae in ovariectomized ewes: a light microscopical study. Tijdschr. Diergeneesk. 100, 436-444.

Wright, R.W., Jr \& Bondioli, K.R. (1981) Aspects of in vitro fertilization and embryo culture in domestic animals. J. Anim. Sci. 53, 702-729. 